\title{
Values, change and inter-generational ties between two generations of women in Singapore
}

\author{
PEGGY TEO*, ELSPETH GRAHAM $\dagger$, BRENDA S. A. YEOH* \\ and SUSAN LEVY†
}

\section{ABSTRACT}

Personal values are framed by social contexts and carried through a person's lifecourse, but are sufficiently malleable to adapt to changing conditions. The dynamic character of personal values should be more frequently recognised in studies of inter-generational ties. This study examines the relationships between two generations of Singaporean women and their divergent values about gender roles, preference for the gender of children, family formation, care-giving and living arrangements. Younger women embrace more western views, while their older counterparts uphold Confucian values. Previous studies have tended to characterise inter-generational ties as conveying 'conflict' or 'solidarity', but here the concept of 'ambivalence' is employed to show that contradictory values coexist, and that inter-generational ties encapsulate the negotiated outcome of complex attitudes, values and aspirations.

KEY WORDS - inter-generational ties, ambivalence, change, lifecourse, gender roles, family, Singapore.

\section{Introduction}

Declining birth rates in many developed countries have led to more 'vertical' family structures. Lower mortality and fertility rates have increased the number of living generations in the average family, while the number of people in the younger generations has declined, with the result that multi-generational family trees have come more to resemble beanpoles than pyramids (Bengston, Rosenthal and Burton 1990; cited in Bengston and Putney 2000). Given this transformation, Pillemer and Suitor (1992) and Suitor et al. (I996) argue that more attention should be

* Department of Geography, National University of Singapore.

$\dagger$ Department of Geography, University of St Andrews, Scotland. 
paid to inter-generational relationships, especially parent-child and grandparent-grandchild ties. They argue that values and expectations are particularly important in determining the dynamics of the relationship between older people and their relatives. To date, research has tended to focus only on the quality of these relationships, namely whether there is solidarity or conflict in the family's care of older members, because these qualities have a significant bearing on the provision of material and emotional support both by and for older people (Finch and Mason I993; Lye 1996).

While the focus on the quality of inter-generational relationships has been productive, this paper responds to an important criticism by Connidis (2000) and by Luescher and Pillemer (1998), that insufficient attention has been paid to social change as a factor in inter-generational ties. For Elder (1978) and Hareven (1996), the historical conditions that affect people at all stages of the lifecourse must be documented. They argue that an understanding of the problems that older people and their families currently face requires knowledge of the larger processes of change that have affected lifecourse transitions, family patterns and generational relations. Family relations in old age are moulded by not only present circumstances but also individuals' histories and the specific historical circumstances that have affected them. The adaptations of individuals and their families are therefore contingent on the pathways by which they reach old age (Hareven I996).

This paper examines the changing form and function of inter-generational ties in Singapore. It has two more specific objectives, to identify the lifecourse stages at which ambivalent inter-generational relations occur within families, and to examine how the ambivalence is managed and how it affects inter-generational ties. Singapore offers a useful setting in which to study various influences on inter-generational values, attitudes and relationships, because over the last 30 years it has experienced rapid and significant socio-economic change and become a major player in the global economy. At the same time, the dominant norms regarding the family and family ties have changed.

To elucidate the impacts of change, the paper focuses on a set of intergenerational relationships that were initially formed by expectations influenced by Confucian principles, but which more recently have been affected by western values. It examines the changed expectations about gender roles, family formation and maintenance, about the care of the very young and of older people, and about various living arrangements. It is accepted that many other factors may affect the 'harmony' and solidarity of an individual inter-generational relationship, and that some may be specific to a birth cohort or a cultural group. This case study focuses on 
the reproduction and maintenance of families in Singapore's Chineseorigin population (which forms 76.8 per cent of the total). Family continuity is a matter of great importance in Chinese societies throughout Asia (for studies of other Asian societies, see Bengston et al. 2000; Chow 200I; Koyano 2000; Sun and Liu 1994).

\section{A framework for analysing inter-generational relationships}

One of the most popular organising frameworks for the study of intergenerational relationships in later life has developed from the concept of solidarity (Luescher and Pillemer I998). It supports propositions of the form: consensus builds solidarity while its antithesis, conflict, gives rise to problematic relationships fraught with difficulties and pain (Bengston and Harootyan 1994; Roberts, Richards and Bengston I99I). In this conception, shared values across generations are the basis of the normative obligation to provide help and a foundation of enduring ties between parents and children. This much-used framework is criticised for its portrayal of a 'love-hate' relationship, 'vacillating between images of mistreatment and abandonment, on the one hand, and comforting images of solidarity on the other' (Luescher and Pillemer i998: 414). In reality, inter-generational relationships are not experienced in this dualistic manner but are more complex and ambivalent. Connidis (2000: i I7), for example, has suggested that solidarity has the following six dimensions:

- associational (type and frequency of interactions and activities);

- structural (such as geographic distance that may prevent interaction);

- functional (as in the exchange of assistance and support);

- affectional (sentiment);

- consensual (agreement between generations); and

- normative (extent of shared values between family members).

The six dimensions may overlap but nonetheless represent well the multidimensional nature of inter-generational relations. The posited complexity is a useful corrective to the still widespread tendency to overlook diversity and to treat problematic relationships simply as the outcome of a lack of solidarity. Recently, however, it has been suggested that the dichotomous description of inter-generational relationships should be replaced by a more complex representation, one that recognises and elucidates the coexistence of conflict and solidarity.

Using the rubric 'ambivalence', this perspective suggests that conflict and contradiction do not invariably lead to antagonism, nor that their absence equates with parent-child solidarity (Connidis 2000; Luescher 
and Pillemer 1998). Rather, it is posited that the two co-exist and that inter-generational relationships alter according to the articulation and resolution of conflict and contradiction in peoples' everyday worlds. Contradictions have both subjective manifestations as well as tangible effects, as in action and upon the distribution of and access to resources (Connidis 2000). The notion of ambivalence immediately raises questions. What are the structural forces and individual interests that create contradictions and conflicts? Are relationships static and uniform? This paper will show that inter-generational ties and exchanges are dynamic, and evolve according to circumstances.

In addition to ambivalence, recognition is also given to the idea that gender plays a significant role in how the lifecourse is shaped. An individual's experiences at one point shapes their subsequent lifecourse, but the opportunity structures for men and women differ, giving rise to contrasting biographies for men and women. Race, age and class interplay with gender, as acknowledged in many studies (Arber 1995; Casalanti I999; Osmond and Thorne I993). According to Ray (I996), there are three categories of feminist research: feminist empiricism, which uses traditional scientific methods to draw attention to gender bias; the feminist viewpoint, which attempts to redress differences by espousing an overtly political agenda; and post-modern feminism, a 'critique of language, discourse and research practices that construct knowledge' (Ray i996: 675). Regardless of the approach, gender-sensitive gerontological research admits that 'gender is not a property of individuals but a socially prescribed relationship, a process and a social construction' (Hare-Mustin and Marecek 200I: IOI). Thus masculine and feminine ways of being in the world and relating to others is socially conditioned and imbued with socially-constructed power relationships, many of which are institutionalised (Arber i995; Casalanti I999; Moen 200I). The inequality of power relations weaves into the fabric of all social networks, including inter-generational relationships.

Research has shown that people actively construct and navigate their life paths (Giddens I984). Conceived as agents, individuals act with information and discernment, even within constrained social structures (Sen I990; Thrift 1983). Agency credits players with abilities to negotiate their positions relative to each other and in response to structural conditions. This study incorporates this idea and examines women as active progenitors of their identities in changing contexts. It is argued that as they navigate the many transitions in their lifecourse, their conceptions of women's identity and role alter. Reflecting a key theme in the lifecourse approach, a gendered approach also investigates linked lives; in the case of this study, the relationships between parents and adult children in specific social contexts (Antonucci i994). ${ }^{1}$ By unravelling the reflective 
constructions of life's pathways, attention is also drawn to the constraints imposed and opportunities created by government policies.

The framework proposed here benefits from two influential theoretical orientations, namely post-modern and feminist theories of the family. These views share a 'distrust for dualistic thinking, e.g. pitting solidarity against conflict, and instead dealing explicitly with contradiction and paradox in social relations' (Luescher and Pillemer I998: 4I5). The postmodern perspective of contemporary society acknowledges change as important and recognises multitudinous social relations. Family life is therefore characterised by plurality (Gubrium and Holstein I994) and is 'diverse, fluid and unresolved' (Stacey i990: I7).

Postmodernism's rejection of essentialism and reductionism therefore suggests that ambivalence can be a useful tool in the analysis of intergenerational relationships. In addition, feminist theory challenges the idea of a harmony of interests among all members of a family. From reproductive control to the household division of labour and parenthood, there are always irresolvable differences (Osmond and Thorne I993). While the care of older people and young children can be meaningful and helps 'connect' the family, it can also oppress women (Connidis 200o). As socioeconomic contexts change, these paradoxes manifest themselves in the value systems of society and therefore influence inter-generational ties in diverse ways.

\section{Methodology}

The study's focus on values, change and relationships across generations made a qualitative method of investigation appropriate. In-depth interviews with three members of 2I family groups were conducted: an adult married woman, her spouse, and her mother or mother-in-law. The adult married women and their spouses are referred to as the 'parent generation', while the 'grandparent generation' refers to the mothers or mothers-in-law and their spouses (Table I). This paper concentrates on interviews with women as the main care-givers of older people and those primarily responsible for social and biological reproductive roles. Men's views are, however, also analysed in relation to female views, and are presented in the paper. Respondents in the parent generation were aged from 27 to 42 years, and in the grandparent generation from 49 to 72 years of age.

The women who were interviewed were all married except for two in the grandparent generation who were widows. Most in the parent generation had children; the average was I.4, while those in the grandparent 
T А в L E I. Educational, occupational and living arrangement profiles of the 63 respondents

\begin{tabular}{|c|c|c|c|c|c|}
\hline \multirow[b]{2}{*}{ Characteristic } & \multicolumn{2}{|c|}{ Parent generation } & \multirow{2}{*}{$\begin{array}{c}\text { Grandparent } \\
\text { generation }\end{array}$} & \multicolumn{2}{|c|}{ National profile $^{1}$} \\
\hline & Male & Female & & Male (\%) & Female $(\%)$ \\
\hline \multicolumn{6}{|l|}{ Highest educational attainment } \\
\hline No formal education & - & - & IO & 7.1 & 7.6 \\
\hline Completed primary $^{2}$ & - & - & I & 9.8 & 10.7 \\
\hline Upper secondary ${ }^{3}$ & 7 & 7 & 7 & $47 \cdot 4$ & 52.8 \\
\hline Tertiary $^{4}$ & I4 & I4 & 3 & $35 \cdot 7$ & 28.9 \\
\hline Total & $2 \mathrm{I}$ & $2 \mathrm{I}$ & $2 \mathrm{I}$ & IOO.O & IOO.O \\
\hline \multicolumn{6}{|l|}{ Employment status } \\
\hline Working & 20 & I7 & 5 & 96.6 & 71.0 \\
\hline Part-time/not working/retired & I & 4 & I6 & $3 \cdot 4$ & I9.0 \\
\hline Total & 2I & $2 \mathrm{I}$ & $2 \mathrm{I}$ & 100 & IOO \\
\hline \multicolumn{6}{|l|}{ Living arrangement } \\
\hline Co-resident with adult son & na & na & 2 & - & - \\
\hline Co-resident with adult daughter & na & na & 4 & - & - \\
\hline
\end{tabular}

Notes: I. Characteristics of the parent generation. 2. Completed primary school leaving certificate. 3. Gained General Certificate of Education Ordinary or Advanced ('O' or 'A') Certificate from an institute of technical education. 4. Completed university or polytechnic course. na, not available. Source: Authors' survey. For national data, Department of Statistics (200I, 2002a).

generation had had on average 3.7 children. Although most women of reproductive age in Singapore have no more than 'upper secondary' education, the selected sample included several with tertiary education (Table I). The rationale for the selection of the sample was grounded in Singapore's pro-natal policies which, although not targeted at any particular group of women, clearly favours those who are better educated and have higher incomes (see Teo and Yeoh I999 for further discussion). The sample of adult women of the parent generation replicated the current split of Singapore's female population between those who do and those who do not work. Co-residence with the grandparent generation as well as living-apart situations were taken into account but, given the study's resource constraints, the prime consideration was to gain consent to interviews from the three related members of each family.

The in-depth interviews were conducted between September 200I and August 2002. They were taped at the homes of the respondents and lasted an average of two hours. Only the interviewee, the interviewer and an assistant who managed the tape recorder were present. Other members of the household were kept away so that they would not know what had been said by the other participants in the family unit. The interviews were conducted in English, Mandarin or in a Chinese dialect. The tapes were translated where necessary and transcribed. 


\section{The social demography of Singapore ${ }^{2}$}

It is expected that the population in Singapore aged 65 and more years will increase from I0.2 per cent in 2000 to 18.4 per cent in 2030. Those aged less than i6 years decreased from 68.I per cent in 1970 to 30.I per cent in 2000 (Department of Statistics 2002a). The percentage of the female population who were aged 60 and more years rose from 9.8 per cent in I990 to I0.I per cent in 2000. Among Singapore's older people, 73.7 per cent live in a household in which one or more of their children are present, I3.9 per cent live only with their spouse, and I2.3 per cent live alone or with unrelated persons. Among the older women, 76. I per cent live with a child, I0.3 per cent with their spouse, and I3.6 per cent alone or with unrelated persons (Department of Statistics 2002 b). Of all today's households in Singapore, 21.4 per cent include at least one person aged 65 and more years, little different from the 20.7 per cent io years ago (Department of Statistics 2002 b).

Childbirths are increasingly delayed in Singapore. By 2000, almost half of ever-married women aged less than 30 years, and I4 per cent of those aged $30^{-}-39$ years, had not had a child. In addition, one-child families are becoming more common. Among ever-married females aged 30-39 years, 24 per cent had only one child in 2000 compared to 2I per cent in 1990. For women aged $4 \mathrm{O}^{-}-49$ years, the proportion was 15 per cent in 2000 compared to I i per cent a decade before (Department of Statistics 2002c).

This brief demographic profile of Singapore indicates some likely influences on inter-generational ties. Population ageing coincides with a shrinking of the family unit. In the future, there will be fewer people to look after older people. Moreover, the state expects the costs of health care to rise (Inter-Ministerial Committee on Health Care for the Elderly 1999). The combination of these trends has important implications and warrants more study of the trends in inter-generational relationships and exchange.

\section{Conflicting gender norms across generations and inter-generational ties}

Singapore's rapid development has engendered new expectations about productive work and social reproductive tasks. Female labour force participation rose from 28.2 per cent in 1970 to 48.8 per cent in 1990. By the 2000 census, for the first time a majority of women (50.2 per cent) were in the workforce (Department of Statistics 2002 $a$ ). In the study sample, 8I per cent of women in the parent generation were in work, and most had had at least upper secondary education (and two-thirds had had tertiary 
education). By contrast, women in the grandparent generation rarely worked outside the home. If they did, either their wages were low or they worked informally and were often not paid: many were considered as helpers, as in a family business. The expectations of the two generations of women are therefore markedly different with reference to both social reproductive tasks and productive work.

The women's commentaries on the roles that women play indicate the stark changes over the last generation in the ways in which tasks are managed, time is divided, and living arrangements are made. The last were not always negotiable outcomes, as one participant explained. She had formerly been a seamstress and lived apart from her daughter, who was a part-time doctor and trying to have children:

Women of the past were pitiful ... unlike women today who are more fortunate. Nowadays, the husbands would help you at home even if you're not working or not busy. We didn't have that in the past. Husbands were male chauvinists. Once they got home, they wouldn't ask you about anything and they wouldn't care about anything. We had to be responsible for everything ... You had to make sure everyone had their fill [of food]. You had to cook and whatever else. By the time you finished, you'd be very tired and would go to bed (Mrs Sng, aged 62 years). ${ }^{3}$

Another member of the grandparent generation, Mrs Tang aged 56 years, helped her husband at his business for a few hours a day. Her daughter worked in human relations, had one child and lived in Mrs Tang's house. Mrs Tang explained:

We used to live with our mother-in-law in old houses during those days [and] there were a lot of conflicts in big families. When I lived with my mother-inlaw, there was a lot of mo cha [friction] ... In a typical Singapore household back then, there were uncles, aunts and so on, plus mother-in-law, father-in-law. There were at least five families - five families, not people. Mothers-in-law had a lot of power then ... so everyone vied for their favour and everybody ended up attacking one another and so on. There was discord and no harmony. Of course, mothers-in-law also showed favouritism. Those who knew how to sweet-talk her were treated better. As a result, the family [experienced] friction.

Women who belong to the grandparent generation faced many more constraints during their early life. Twelve of the 21 older women lived in multi-generation households and found that they were in a relatively weak position compared to other members of the household. As seen above, this had been the case for Mrs Sng in relation to her husband, and for Mrs Tang in relation to her mother-in-law. In contrast, women in the parent generation have had more employment opportunities, and have preferred to work rather than be dependent on their spouses. Engagement in productive work had given them advantages that their mothers and 
mothers-in-law had not had. Even among those who did not work, the option to return to work was always present in their minds, as explained by a $3^{8}$-year-old part-time doctor who was trying to have children:

I think that for women, the family is very important. But at the same time, being trained as a doctor and also knowing that a person who works in society is quite different from one who just stays at home, I just want to be in society and contributing at the same time ... I find that people who don't work and just stay at home, [they] sort of get out of touch. They, they are just kind of different (Ling Hui, aged 38 years).

Similar views were expressed by less educated women. Rachel, a 3-yearold clerk with two children who lived apart from her parents and in-laws, said, 'If you stop [work], there's a gap in society', referring to a lack of engagement with reality. 'At least [if] you go out and work, you know what to do; then [there's] also ... income.' Given the widely different value systems held by the two generations of women, some adjustment is necessary, especially on the part of the grandparent generation to the expectations of the younger generation of women. The position was described well by a woman who lives apart from her marketing-executive daughter-in-law (no children), when she was interviewed about her work experience as well her views about the current generation of working women:

Last time [ $=$ in the past] when you worked, you didn't have to work ... at night ... especially civil servants, [they worked] 8.00 am to $4.30 \mathrm{pm}$ and then were back home and didn't care about what was in the office. Now it's different, now you might work until the middle of the night ... Even women have to work late. Also, [women then] had to sacrifice a lot. I stop[ped] applying for promotion ... because I want [ed] to spend more time with my children. ... Once you [get] promote[d], they will send you far, far away so by the time you come back, it will take long hours. So you have to [make] sacrifices (Mrs Chee, aged 6o years).

Mrs Chee alludes to the longer working hours that women face today. In addition, promotion is far more possible for the present generation than at the time she worked. Not only are young people working long hours, they are also more ambitious and more are willing to forgo raising a family for a career, which was unheard of during Mrs Chee's time. Although the older generation regards social reproductive tasks as their main role in society, they have an ambivalent attitude towards productive work among the women of today. The ambiguity comes from the realisation that working women of the present generation contribute quite substantially to the income of a modern household. As the cost of living rises in Singapore, the older generation of women are resigned to the fact that a comfortable lifestyle would only be possible if both husband and wife worked. One woman, Mrs Tang, said with reference to the current generation of young women, 'the most important pursuit is earning money ... [it] doesn't solve 
everything but money is able to solve a lot of problems'. Another woman, a homemaker who lived apart from her daughter-in-law, a clerk with two children, said:

Everything is more expensive today, and there's a cost to everything. In the kampong days [referring to the past], it was not like this. The education system today is different, you have to start studying from young. This costs money, like [my grandson's] monthly school fees, and the costs of textbooks are high. Everything is expensive ... you cannot afford to give birth these days (Mrs Yeo, aged 53 years).

One interview with a husband, who was a contractor and father of three children, and whose mother and mother-in-law lived in a separate household nearby, prompted these comments:

Actually, honestly, there was no need for Laura [the respondent's wife] to go back to work ... But my parents think, 'What's the problem with Laura going back to work?' [We] have a maid, why should she stay at home? My parents ... are opinionated and they express [themselves] strongly. Compared to the rest of my siblings, we're not as well off. And they [my parents] say, 'Your brother and your sisters are much better off than you. Their wives still work, why can't you be the same?' (Eugene, aged 40 years).

With new opportunities in the workforce, competition for jobs is keen and tensions surface between the two generations about traditional gender roles. The grandparent generation seems keener to embrace the shift than the parent generation of women. They express misgivings, as revealed in the following responses of $\mathrm{Mdm}^{4} \mathrm{Lam}$, a widow who had retired from helping in her husband's business. She was describing her daughter-in-law who, although well qualified, did not have a paid job:

Her own mother told her [to continue working] when she had her first child [and] to get a maid to look after the child. She [her mother] said she would go up there once in a while to keep a lookout [so] she can go out to work. After all, she studied so much it is such a waste. Her father told her that too. She didn't want to. She wanted to look after the children herself [and] to teach them herself. [I think] of course that she should go out and work. Otherwise, it would be such a waste. She went all the way to study in Australia. Who doesn't work after they get married? She is the only one! All my friends asked about it. 'She no longer works! Such a waste', they all said. (Mdm Lam, aged 7r years)

This appreciation of changing economic and social realities is the outcome of the years of struggle that older Singaporeans experienced when the nation strove to achieve independence from the British and to invigorate the economy. Some in the current generation of Singaporeans are accused by the Prime Minister of being 'fair weathered' and unwilling to face up to economic difficulties (Anon The Straits Times 2002). Between 1990 and 1997, the country's annual economic growth rate averaged seven per cent 
(Department of Statistics 200I: 2). Some who entered adult life in this period are affluent and focus on quality of life goals rather than breadand-butter material issues. It is therefore not surprising that some women, when they have young children want to stop work to give them the best quality of care. Their payment contributions to the Central Provident Fund $(\mathrm{CPF})$, or state social security system, places them in a stronger position to exercise choice than earlier cohorts of women at the same stage of the lifecourse. While some older women of the grandparent generation accept this, the majority would prefer to see the parent generation of women in work.

Significant inter-generational differences were also discerned in attitudes to family formation and maintenance. For the majority of the grandparent generation, family formation was foremost when they had first married. Nearly all the 2 I women of this generation had had their first child within one year of marriage. With changing economic circumstances, many first births are now delayed. Although most of the women in the grandparent generation would have liked their children to start a family with the least delay, most accepted that this was unlikely to happen. One woman, Mrs Yip, aged 66 years, lived with her daughter-in-law who was an engineer and had two children. When asked if her daughter-in-law wanted more children, she replied, 'She says that she doesn't have the time. She went back to work'. Another woman, Mrs Tng, aged 55 years, is a manager in a printing firm. Her daughter is a marketing executive, lives with her, and has no children. Mrs Tng compared what usually happened at the time she married to the situation today:

I think at that time, [it was normal] to have kids as soon as you get married ... There's no such thing now. Modern kids ... wait two, three years. They must get themselves all set up first before they start thinking ... of a family. Previously it wasn't that way. I hope that she [the daughter] will have more, but she doesn't want more. People these days are like that. They have only one ... only one, very lonely, very lonely and lonesome. When the children see others who have siblings, they feel that it is very good.

There is also ambivalence about the preferred gender of children. Some values are resilient to socio-economic change, not least the preference for sons in Chinese households (Croll 2000). As Table 2 shows, the survey corroborated this preference among our respondents, but it also found both tensions and changing attitudes. These appear to have been necessary to consolidate inter-generational ties. While there is still a strong son preference in the grandparent generation, it is much less evident in the parent generation (Table 3). Women of the grandparent generation certainly felt pressure from their parents and their in-laws: "the older folks preferred sons. I had two daughters first. So the older folks were not very 
T A B L E 2. Preferred gender of children among grandparent generation

\begin{tabular}{lccc}
\hline & Sons & Daughters & No preference \\
\hline Educated $^{1}$ & 6 & I & 4 \\
Not educated & 7 & - & 3 \\
Total & I3 & I & 7
\end{tabular}

Notes: I. Educated is defined as having a few years of formal education at least equivalent to the current primary school level.

Source: Authors'survey.

T A B L E 3. Preferred gender of children among parent generation

\begin{tabular}{lcccc}
\hline & $\begin{array}{c}\text { First child to } \\
\text { be a son }\end{array}$ & $\begin{array}{c}\text { First child to be } \\
\text { a daughter }\end{array}$ & $\begin{array}{c}\text { One child to } \\
\text { be a son }\end{array}$ & No preference \\
\hline Upper secondary & 2 & 4 & 4 & 3 \\
Tertiary & 3 & 5 & 5 & I6 \\
Total & 5 & 9 & 9 & I9 \\
\hline
\end{tabular}

Source: Authors' survey.

happy. ... When I was pregnant with the third, I was afraid that the child might be a girl, but fortunately it was a son' (Mdm Lam, aged 7I years). But women in the grandparent generation had different views about their grandchildren:

Boy or girl is the same if you take care of them well and nurture them well. Girls have their mother's interest at heart. Some boys are good but their wives are not (Mrs Yang, aged 65 years).

It is not necessarily good if you only had sons, right? Sons are not necessarily good. ... I feel that once the sons get married, they follow their wives' side (Mdm Lam).

The grandparent generation seems to have selectively reconstructed tradition (Graham et al. 2002). During the stage of their lifecourse when they were reproducing, bearing sons to continue the family name was an important consideration and strongly influenced their reproductive choices. In the current situation, as women's contributions to the economy become more obvious and men participate more in social reproductive tasks, they seem willing to forgo those values. Women in the parent generation had different and variable views, as illustrated in the comments of Agnes, a 33-year-old with two children and who did not work:

I had [a daughter] and when I was going to have the second child, I was hoping and hoping it would be a girl. Perhaps I thought it is more economical. Her clothes will go on to the second one. But after some time when I realised that it's 
actually a boy, I got used to the idea. Okay, it's a girl and a boy ... I guess it's because of my background. Two boys in a family [are] enough, I want a girl. I prefer girls. Girls are closer to their mum, I guess.

Whether the issue is work or son preference, each generation applies their own value system, and the divergent values bring inter-generational relations under strain. But rather than allowing the divergence to threaten the solidarity of such ties, women in the grandparent generation reconcile themselves to the younger generation's values. They recognise that adaptation is a necessary part of contemporary life. As to agency, a shift in the power relationship between the individuals in the grandparent and parent generations means that more tolerance is required. The narratives about the desired number of children and the decision not to work indicate continuous negotiation of the inter-generational balance. While a few decades ago the older generation strongly influenced their children's decisions, this is no longer the case.

\section{Inter-generational ties and living arrangements}

Changed values with respect to gender roles and family formation have tangible implications for inter-generational relations. Child-care and living arrangements in Singapore depend a great deal on the roles specified for different groups of people as perceived by themselves and by others. In Singapore, parents depend on the grandparent generation to assist in care of the very young (Teo I997; Teo and Mehta 200I). The arrangements vary. Among our respondents, the children of three sets of parents who worked full time lived with their grandparents and only went to their parents' home at weekends. There were Io cases in which the children of working parents stayed with the grandparents during the day. For two working mothers, the grandparents came occasionally to their homes to look after the children. Some of these arrangements compromised grandparents' expectations about their role and gave rise to conflicts. One woman, Mdm Sim, aged 50 years, lived apart from her daughter who was a public relations officer and had a young child. She spoke about looking after her grandchild:

If [my daughter] lets outsiders baby-sit, then it is not too good. I am very careful when I look after her [the baby]. She lets others take care of her baby, [but it would be] better that she does not work. I asked her to change jobs, but she doesn't listen. She is very career-minded.

Another woman, Mrs Seetoh, aged $5^{8}$ years, lived apart but very close to her daughter who was an administrative officer and had two children. 
T A B L E 4. Preferred living arrangement on reaching older age by generation

\begin{tabular}{lcc}
\hline & Grandparent generation & Parent generation \\
\hline Prefer to stay with spouse/on own & I2 & 23 \\
Prefer to stay with son & 3 & - \\
Prefer to stay with daughter & O & 3 \\
Does not matter whether son/daughter & 5 & - \\
Not stated/not sure & I & I6 \\
Total & 2I & $4^{2}$ \\
\hline
\end{tabular}

Source: Authors' survey.

She related that her daughter once asked for her help, to which the reply was:

It's best [for the child] to have her own mother to take care. I was young then so I could help. Now that there's one more [grandchild] and I'm older already, I don't really wish to take care of so many. I have to cook and take them to tuition and so on.

Expectations with regard to child-care arrangements indicate that reciprocity and solidarity play out against each other. Following George's (I986) argument, while the 'profit' and 'loss' for the partners in a relationship should be equitable and reciprocated, when 'solidarity' prevails, help is rendered without the expectation of a return. The respondents expressed both values with regard to child-care, and evinced ambivalence about their relationship. While older women and their spouses want to help the younger generation of parents with young children, they also resent their lack of support and taken-for-granted attitude that help will be forthcoming.

Turning to living arrangements, Singapore is a patriarchal society and men have customarily been expected to take in their parents, but even this practice is declining (Table 4 ). Burden and care expectations are altering across the generations, and multi-generational extended households are becoming less common.

Today, even the grandparent generation is no longer willing to uphold the traditional family. As an example, Mrs Ang's husband's family built an apartment block with six units for each member of the patriarchal family. Now 63 years of age, she lived in one of the units with her husband, unmarried daughter and oldest son. He was married with a 20-year-old son. She made a measured assessment: 'Having a big family is good. You can take care of each other. If you have something to attend to, you can help each other out. It is good to stay together ... but it is only good when you can get along with each other'. Another woman, Mrs Yuen, aged 
49 years, living apart from her daughter who worked as a project manager and had one child, described her ideal living arrangement:

In my heart, I don't wish to live with them ... they [the adult children] can bring [the grandchildren] here if they like. We [the grandparents] can take care of the [grandchildren]. They [the adult children] can take them back home at night. It is better like that. We can go anywhere we like. It's our own business whether the house is clean or dirty. If we were staying at their [adult children's] house, we would feel bad if we damaged anything [and they] would be unhappy.

The grandparent generation manifests countervailing norms about living arrangements. On the one hand, they desire independence but, on the other hand, still value the emotive support that comes from living together. The parent generation arguably has more consistent ideas about what they want and expect for their family and for themselves. As Evan, a $3^{8}$ year old businessman who has two children and lives apart from his mother and his in-laws, said: 'I will end up depending on myself. The people in the coming generations will have to depend on themselves. It is impossible to have children for the sake of them taking care of you when you are old. These [views] are outdated.' The differences of attitude and expectation underlie the relativistic character of today's inter-generational ties. Whether living or child-care arrangements are in mind, there is continuous negotiation and adaptation, as agency becomes stronger or weaker. The resolution also reflects the relative abilities of individuals to assert their preferences.

\section{Ambivalence about autonomy and dependence}

Autonomy and dependence are the opposite poles of inter-generational relationships in most contemporary societies (Luescher and Pillemer ig98: 4I7). While women in the parent generation want their mothers to continue to fulfil their roles and wish to learn from them, they also want to lead independent lives. Two expressions of these views are instructive:

I think it's very important ... what my mother imparts to us. It's family teaching, her values ... Like now, I actually ask my daughter to hand the money [monthly allowance] to my mother ... She'll [the young daughter] ask me, 'Why?' I say, ' [sometime] your mummy will be old and you'll have to take care of me'. So this is like educating them from young. This is just [the way that] my mother has been educating us (Vanessa, aged $3^{2}$ years, a human relations manager with one child and who lives in her mother's house).

My mother has always been there for us. Always. When I said I'm sick ... she would come and pick me up. ... My mum always came back at $5.30 \mathrm{pm} \ldots$ and she would always cook dinner even though we had a maid. She would sit down 
and go through our schoolwork with us and, she talked... If my mum can achieve all that, I must achieve that too, if not more, or else I would fail my role as a woman, I think. (Siew Hwee, aged 29 years, a corporate communications manager with two children and who lives apart from her mother-in-law and mother).

Emulating mothers as care-givers and 'kin-keepers' locks older women into certain roles and activities and impedes them from planning and doing things on their own. Some resentment is therefore generated. As Mdm Sim said, 'I do not really like it but there is no choice, so I just help look after [the] children till I am sick of it already. I do not like to look after children'. Another woman, Mrs Seow, aged 6i years and a retired seamstress, recounted an explicit clash of views:

My son-in-law said, 'Mother, you ask me to have children, [but] you have to look after for me.' That was how he spoke to me. Frankly speaking, I feel very tired now. ... I am now over 6o years old [and] have been working since I was young. I want to have time to myself ... sometimes I want to go for holidays.

Many inter-generational ties between the grandparent and parent generations are tainted by irresolution. Depending on the participants' needs and on their capabilities in meeting the demands, a harmony of interest is not always achieved. Instead, the qualities of the linked lives depend a great deal on the shifting co-existence of conflict and solidarity.

\section{Policy and changing inter-generational ties}

In rg89 the Singapore Advisory Council on the Family and the Aged published a report which spelt out the need to reinforce Asian values regarding the support of older people (Ministry of Home Affairs ig89). The Public Awareness Programme on Ageing and the Parent Education Programme were established to promote in schools and the media filial piety, courtesy and respect for older people, and strong inter-generational ties. In addition, the Parent Maintenance Act I995 enabled older people to bring their children to court if they neglected to support them financially. Although this was unpopular with the public (70.2 per cent in a newspaper poll felt the Act was harsh), I27 cases were heard in the Family Court in I999 (Anon The Straits Times 2000).

The promotion of inter-generational ties among Singaporeans aims to strengthen the solidarity of the relationship as depicted in the traditional Asian family. There is encouragement for older people and their families to live in close proximity. The Housing and Development Board (HDB), the public housing agency, ${ }^{\mathbf{5}}$ initiated a 'Joint Selection Scheme' which assists parents and their children (above 2 I years of age) who apply for separate 
flats in the same block or on the same housing estate. A variant is the 'Multi-Tier Family Housing Scheme'. This offers preferential housing allocations, with shorter-than-the-average three-year waits, reduced downpayments, and higher loans. Applicants may also request large flats with space for two independent households. In the longer-established housing estates where few new flats are available, the CPF 'Housing Grant Scheme' gives grants of approximately US\$30,ooo towards the purchase on the open market (rather than through the HDB) of a replacement flat.

From the state's viewpoint, the promotion of family responsibility has many advantages: it keeps the responsibility to care for older people in the family and prevents its shift to the state. The narratives reported in this paper about child-care and living arrangements suggest however that older people prefer reciprocal family relationships and more choice in their roles. Worn down by the commitments of child-care, many expressed a desire to stop or do less. As family size reduces and child births are delayed, and as life expectancy increases and more women participate in the work force, the maintenance of inter-generational family ties will become more problematic. The government's policies should be reviewed to take into account the preferences and needs of all members of households and extended families. If the focus is exclusively on reinforcing solidarity, policies will be inappropriate for the modern household. Policies must respond to new work demands and leisure opportunities.

\section{Conclusions}

In Singapore, inter-generational ties are adapting to changing socioeconomic conditions. In this study of the relationships between women of consecutive generations, it has been shown that a sense of ambivalence predominates. While both the discourse about 'Asian' values, such as filial piety, and strong mutual practical inter-generational support continue to infuse family life, divergent values between the generations are emerging. The traditional inequality between consecutive generations that was associated with the older generation's pressure on younger members to fulfil the transmission of culture and social values has been eroded (Thang 20ог: 4). Inter-generational relationships are increasingly seen in functional and convenience terms, to the extent that some of our older respondents complain about the insensitivity of the parent generation to their needs.

As for living arrangements, although the majority of older people in Singapore still live with adult children, tensions have surfaced. This study has found that while many mothers in the parent generation wish 
their mothers to be child-carers, and hence prefer co-residence, many grandmothers express a preference for greater autonomy and independence, as in western countries. For the grandparent generation, ambivalence manifests itself in the desire for the generations to remain closely bound by mutual material and emotive support, and the simultaneous reluctance to sacrifice personal autonomy. Many said that while they were prepared to help with the grandchildren, they would prefer to live apart and maintain their own home. It also appears that traditional preferences about the number, sex and spacing of children are weakening in the parent generation (Barber 2000; Barber and Axinn 1998; Chi and Hsin 1996).

Despite the state's espousal of Asian patriarchal family structures and traditional family values, following three decades of women's increasing workforce participation, gender-differentiated norms regarding productive work and family reproduction and maintenance are increasingly being challenged. Engagement in paid work outside the home is now the norm for Singaporean women in the parent generation, even among the less educated. An interesting indication of the speed of value change is the strong preference of women in the grandparent generation for their daughters to be employed and at the same time to provide them with financial, physical and emotional support and care. While their own lives have been largely dominated by the concerns of the home and the care of children, many older women now take the view that their daughters (and daughters-in-law) should not sacrifice their careers or the material well-being of the family for the sake of homemaking and the children.

In conclusion, our understanding of inter-generational relationships, and of the many transactions between the generations that underpin the functioning of any society, is enhanced by the concept of ambivalence. The dualist representation of relationships that characterised some past research failed to recognise either the dynamism and fluidity of intergenerational ties or the ways in which past and present values in the lifecourses of individuals are interwoven and resolved. Neither values nor relationships are static; nor are they divorced from society or specific times and places. Only if this is recognised can we further deepen our understandings of the ties that bind.

\section{Acknowledgements}

The research reported in this paper was funded by the National University of Singapore (grant Riogoooo36II2) and the UK Economic and Social Research Council (grant Rooo223830). 


\section{NOTES}

I Other links that can be studied are those among adult children, friends and coworkers.

2 As the Chinese comprise 76.8 per cent or the majority of the country's population, the trends described in this section reflects the group's demographic attributes.

3 Either a daughter or daughter-in-law would be one of the three interviewed. The relevant relationship for the study is specified in each case. All names are pseudonyms.

4 'Mdm' indicates that the respondent is a widow.

585 per cent of Singaporeans live in subsidised state public housing provided by the HDB.

\section{References}

Anon 2000. Ordered to support parents: I in 2 default. The Straits Times, 23 February 48.

Anon 2002. PM Goh: are you a stayer or a quitter? The Straits Times, i9 August. Available online at http://straitstimes.asiaone.com.sg

Antonucci, T. C. I994. A lifespan view of women's social relations. In Turner, B. F. and Troll, L. E. (eds), Women Growing Older: Psychological Perspectives, Sage, Thousand Oaks, California, 239-69.

Arber, S. 1995. Connecting gender and ageing: a new beginning? In Arber, S. and Ginn, J. (eds), Connecting Gender and Ageing: A Sociological Approach. Open University Press, Buckingham, I73-8.

Barber, J. S. 200o. Intergenerational influences on the entry into parenthood: mothers' preferences for family and non-family behavior. Social Forces, 79, I, 319-48.

Barber, J. S. and Axinn, W. G. I998. The impact of parental pressure for grandchildren on young people's entry into cohabitation and marriage. Population Studies, 52, 129-44.

Bengston, V. L. and Harootyan, R. A. 1994. Intergenerational Linkages: Hidden Connections in American Society. Springer, New York.

Bengston, V. L. and Putney, N. M. 200o. Who will care for tomorrow's elderly? Consequences of population aging East and West. In Bengston, V. L., Kim, K. D., Myers, G. C. and Eun, K. S. (eds), Aging in East and West: Families, States and the Elderly. Springer, New York, 263-85.

Bengston, V. L., Kim, K. D., Myers, G. C. and Eun, K. S. (eds) 200o. Aging in East and West: Families, States and the Elderly. Springer, New York.

Casalanti, T. I999. Feminism and gerontology: not just for women. Hallym International Journal of Aging, I, I, 44-55.

Chi, P. S. K. and Hsin, P. L. I996. Family structure and fertility behavior in Taiwan. Population Research and Policy Review, I 5, 327-39.

Chow, N. W. S. 200r. The practice of filial piety among the Chinese in Hong Kong. In Chee, I., Chappell, N. L. and Lubben, J. (eds), Elderly Chinese in Pacific Rim Countries: Social Support and Integration. Hong Kong University Press, Hong Kong, I25-36.

Connidis, I. A. 2000. Family Ties and Aging. Sage, Thousand Oaks, California.

Croll, E. 200o. Endangered Daughters: Discrimination and Development in Asia. Routledge, London.

Department of Statistics 200 r. Yearbook of Statistics 200I. Department of Statistics, Singapore.

Department of Statistics 2002a. 2000 Census at a Glance. Available online at http://www. singstat.gov.sg/c200o/census.html [Accessed 23 August 2002].

Department of Statistics 2002 b. Singapore Census of Population 2000 Advance Data Release No. 7: Households and Housing. Available online at http://www.singstat.gov.sg/c20oo/census. html [Accessed 23 August 2002]. 
Department of Statistics 2002 c. Singapore Census of Population 2000 Advance Data Release No. 8: Marriage and Fertility. Available online at http://www.singstat.gov.sg/c20oo/census.html [Accessed 23 August 2002].

Elder, G. H., Jr. I978. Family history and the life-course. In Hareven, T. K. (ed.), Transitions: The Family and the Life Course in Historical Perspective. Academic, New York, I7-64.

Finch, J. and Mason, J. I993. Negotiating Family Responsibilities. Tavistock/Routledge, London.

George, L. K. I986. Caregiver burden: conflict between norms of reciprocity and solidarity. In Pillemer, K. and Wolf, R. (eds), Elder Abuse: Conflict in the Family. Auburn House, Dover, Massachusetts, 69-92.

Giddens, A. 1984. The Constitution of Society. Polity, Cambridge.

Graham, E., Teo, P., Yeoh, B. S. A. and Levy, S. 2002. Reproducing the Asian family across the generations: 'tradition', gender and expectations in Singapore. Asia-Pacific Population Fournal, $\mathbf{1}$ 7, 2, 6I-86.

Gubrium, J. F. and Holstein, J. A. I994. Grounding the postmodern self. The Sociological Quarterly, 34, 685-703.

Hareven, T. K. I996. Historical perspectives on family and aging. In Blieszner, R. and Bedford, V. H. (eds), Aging and the Family: Theory and Research. Praeger, Westport, Connecticut, $13-3$ I.

Hare-Mustin, R. T. and Marecek, J. 200I. Gender and the meaning of difference: postmodernism and psychology. In Herrmann, A. C. and Stewart, A. J. (eds), Theorizing Feminism: Parallel Trends in Humanities and Social Sciences, second edition. Westview, Boulder, Colorado, 78-Iog.

Inter-Ministerial Committee on Health Care for the Elderly i999. Report of the Interministerial Committee on Health Care for the Elderly. Ministry of Health, Singapore.

Koyano, M. 200o. Filial piety, co-residence, and intergenerational solidarity in Japan. In Liu, W. T. and Kendig, H. (eds), Who Should Care for the Elderly: An East-West Value Divide. Singapore University Press and World Scientific, Singapore, 200-23.

Luescher, K. and Pillemer, K. 1998. Intergenerational ambivalence: a new approach to the study of parent-child relations in later life. Fournal of Marriage and the Family, 6o, 413-25.

Lye, D. N. I996. Adult-child parent relationships. Annual Review of Sociology, 22, 79-102.

Ministry of Home Affairs I989. Report of the Advisory Council on the Aged. Ministry of Home Affairs, Singapore.

Moen, P. 200I. The gendered life course. In Binstock, R. and George, L. K. (eds), Handbook of Aging and the Social Sciences, fifth edition. Academic, San Diego, California, 179-96.

Osmond, M. W. and Thorne, B. I993. Feminist theories: the social construction of gender in families and society. In Boss, P. G., Doherty, W. J., LaRossa, R., Schumm, W. R. and Steinmetz, S. K. (eds), Sourcebook of Family Theories and Methods: A Contextual Approach. Plenum, New York, 59i-623.

Pillemer, K. and Suitor, J. J. I992. Intergenerational relations. In Borgatta, E. F. and Borgatta, M. F. (eds), Encyclopaedia of Sociology. Macmillan, New York, 949-55.

Ray, R. E. I996. A postmodern perspective of feminist gerontology. The Gerontologist, 36, 5 , $674-80$.

Roberts, R. E. L., Richards, L. N. and Bengston, V. L. I99ı. Intergenerational solidarity in families: untangling the ties that bind. In Pfeifer, S. K. and Sussman, M. B. (eds), Families: Intergenerational and Generational Connections. Haworth, Binghampton, New York, I -46 .

Sen, A. I990. Gender and cooperative conflicts. In Tinker, I. (ed.), Persistent Inequalities: Women and World Development. Oxford University Press, New York, I23-49.

Stacey, J. I990. Brave New Families: Stories of Domestic Upheaval in Late Twentieth Century America. Basic, New York. 
Suitor, J. J., Pillemer, K., Keeton, S. and Robison, J. I996. Aged parents and aging children: determinants of relationship quality. In Blieszner, R. and Bedford, V. H. (eds), Aging and Family: Theory and Research. Praeger, Westport, Connecticut, 223-42.

Sun, T. H. and Liu, Y. H. 1994. Changes in intergenerational relations in the Chinese family: Taiwan's experience. In Lee, J. C. and Yada, M. (eds), Tradition and Change in the Asian Family. University of Hawaii Press, Honolulu, 319-6r.

Teo, P. 1997. Older women and leisure in Singapore. Ageing and Society, I 7, 649-72.

Teo, P. and Yeoh, B. S. A. I999. Interweaving the public and private: women's responses to population policy shifts in Singapore. International fournal of Population Geography, 5, 79-96.

Teo, P. and Mehta, K. 200r. Participating in the home: widows cope in Singapore. Fournal of Aging Studies, I 5, 2, I27-44.

Thang, L. L. 200I. Generations in Touch: Linking the Old and Young in a Tokyo Neighbourhood. Cornell University Press, Ithaca, New York.

Thrift, N. I983. On the determination of social action in space and time. Environment and Planning I: Society and Space, I, 23-57.

Address for correspondence:

Accepted 22 January 2003

Peggy Teo, Department of Geography, National University of Singapore, I Arts Link, Kent Ridge, Singapore II7570.

e-mail: geoteop@nus.edu.sg 